\title{
Early increase in serum-COMP is associated with joint damage progression over the first five years in patients with rheumatoid arthritis
}

\author{
Maria L E Andersson ${ }^{1 *}$, Björn Svensson ${ }^{2}$, Ingemar F Petersson ${ }^{2}$, Ingiäld Hafström³, Kristina Albertsson ${ }^{3}$,
} Kristina Forslind ${ }^{2,4}$, Dick Heinegård ${ }^{2}$ and Tore Saxne ${ }^{2}$

\begin{abstract}
Background: Currently available biomarkers for the early tissue process leading to joint damage in rheumatoid arthritis are insufficient and lack prognostic accuracy, possibly a result of variable activity of the disease over time. This study represents a novel approach to detect an altered activity of the disease process detected as increasing serum-COMP levels over a short time and whether this would correlate with joint damage progression over the first 5 years of disease.

Methods: In all, 349 patients from the Swedish BARFOT early RA study were examined. Serum-COMP was analysed by ELISA at diagnosis and after 3 months. Based on changes in serum-COMP levels, three subgroups of patients were defined: those with unchanged levels (change $\leq 20 \%)(N=142)$, decreasing levels $(>20 \%)(N=173)$ and increasing levels (> 20\%) ( $N=34)$. Radiographs of hands and feet were obtained at inclusion, after 1, 2 and 5 years and scored according to Sharp van der Heijde (SHS). Radiographic progression was defined as increase in SHS by $\geq 5.8$.
\end{abstract}

Results: The group of patients with increasing COMP levels showed higher median change in total SHS and erosion scores at 1, 2 and 5 year follow-up compared with the groups with stable or decreasing COMP levels. Furthermore, the odds ratio of radiographic progression was $2.8(95 \% \mathrm{Cl} 1.26-6.38)$ for patients with increasing COMP levels vs. patients with unchanged levels.

The group of patients with increasing COMP levels had higher ESR at inclusion but there were no baseline differences between the groups for age, gender, disease duration, disease activity (DAS28), function (HAQ), CRP, nor presence of rheumatoid factor or anti-CCP. Importantly, neither did changes over the 3-month period in DAS28, HAQ, ESR nor CRP differ between the groups and these variables did not correlate to joint damage progression.

Conclusion: Increasing serum-COMP levels between diagnosis and the subsequent 3 months in patients with early RA represents a novel indicator of an activated destructive process in the joint and is a promising tool to identify patients with significant joint damage progression during a 5 -year period.

Keywords: Cartilage oligomeric matrix protein, COMP, Rheumatoid arthritis, Biomarkers, Radiographic joint damage progression

\section{Background}

Rheumatoid arthritis (RA) is a heterogeneous disease with a markedly variable course in different patients. A major challenge for the treating physician is to early upon diagnosis identify patients prone to different outcomes. In view of new developments in pharmacotherapy, it would be optimal to early identify those patients who are likely

\footnotetext{
* Correspondence: maria.andersson@spenshult.se

${ }^{1} R$ and D center, Spenshult Hospital, Oskarström, Sweden

Full list of author information is available at the end of the article
}

to develop a severe disease and enroll them for early aggressive treatment. On the other hand, with reliable prognostic indicators patients who have a potentially mild disease could be spared therapy associated with risks of side effects.

Disease outcome can be defined in different ways, i.e. radiographic joint damage, functional disability or mortality. Obviously these variables are interlinked, but predictors are not entirely overlapping [1]. However, radiographic outcome may be considered a key variable since it reflects

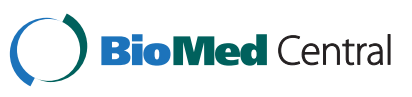


a cumulative effect of inflammation, the tissue destroying process in bone and cartilage and accounts for a great deal of the disability in RA [2-4]. In search of prognostic makers to select patients for early intervention, there is little for the individual patient, while indicators that tell us that a cohort of patients has a higher risk, have been identified providing promise for future work. It is reasonably well established that some clinical and serological variables i.e. female sex, early joint erosions, presence of rheumatoid factor and/or anti-cyclic citrullinated peptide (Anti-CCP) and high inflammatory activity as measured by e.g. Creactive protein (CRP) are negative prognostic signs, but the utility of these is limited when applied on an individual patient basis [5-7].

Another approach which is increasingly being explored is based on the assumption that release of molecules/ fragments from joint tissue into the circulation reflects ongoing tissue turnover. Increased release should indicate accelerated turnover possibly with an emphasis on degradation and if persistent lead to permanent joint damage [8]. This forms the rationale for applying tissue markers to identify patients prone to rapid joint damage progression and to distinguish them from those having a more favourable prognosis.

One such biomarker is cartilage oligomeric matrix protein (COMP, thrombospondin 5). COMP is a $435-\mathrm{kDa}$ homopentameric, extracellular protein primarily identified in cartilage $[9,10]$. Although COMP has also been identified in smaller amounts in normal ligament, meniscus, tendon, synovium, and osteoblasts as well as in scleroderma skin results from e.g. experimental arthritis clearly indicate that changes in serum levels of COMP in arthritis reflect processes in the cartilage [11]. COMP has been studied as a biological marker for diagnostic and prognostic applications as well as for evaluating treatment effects both in RA and osteoarthritis (OA) [12-17]. Thus, COMP serum levels were found to be higher in RA patients with rapidly progressive disease but the prognostic value of single measurements is limited [18-20]. In OA, similar observations have been made but interestingly in this condition changes in serum-COMP over a 1 or 3 year period seems to increase the prognostic utility [21-23]. Furthermore, it was recently shown that serum-COMP levels have a substantial genetically determined component, i.e. to as much as $40 \%$. Thus, in some patients the high levels may not be pathological, which complicates interpretations [24].

Based on the observations that serum-COMP changes over time in individual patients with $\mathrm{OA}$ minimize the effects of the inter-individual variation we hypothesised that early changes in serum COMP during RA may relate to future joint damage. The present study examined this hypothesis in a well-defined prospective cohort of patients with recent onset RA. Alterations in levels of serumCOMP between diagnosis and 3 months were related to radiological outcome in hands and feet over the first 5 years.

\section{Method \\ Patients}

This study comprises 349 patients, who were included in the BARFOT (Better Anti-Rheumatic PharmacOTherapy) early RA study from November 1993 to June 1999. The BARFOT-study is a longitudinal observational multicenter study, where patients were consecutively included after having been diagnosed with RA according to the American College of Rheumatology 1987 criteria [25], provided that they had a disease duration not more than 1 year [26]. After baseline evaluation, regular follow-up assessments according to a defined study protocol were conducted. The present study included only patients where blood samples from inclusion and at 3 months follow up as well as radiographs from inclusion and at five year follow-up were available. Patients not included $(n=124)$ did not differ from included patients regarding demographics, treatment, total SHS, serological or inflammatory markers at inclusion or at the 5 year follow-up in the observational study.

\section{Clinical disease assessments}

Disease activity was measured by the composite index Disease Activity Score calculated on 28 joints (DAS28) [27]. Remission was defined either as DAS28<2.6 [28,29] (EULAR remission) or according to the recently proposed EULAR/ACR remission criteria (scores on the tender joint count, swollen joint count, CRP (in $\mathrm{mg} / \mathrm{dl}$ ), and patient global assessment $(0-10$ scale) were all $\leq 1)$ [30]. Functional disability was assessed using the Swedish version of the Stanford Health Assessment Questionnaire (HAQ) [31].

\section{Biochemical assessments}

At inclusion venous blood samples were taken before the patients started treatment with prednisolone and/or disease modifying anti-rheumatic drugs (DMARDs) and were analyzed by routine methods for erythrocyte sedimentation rate (ESR) and C-reactive protein (CRP). Rheumatoid factor (RF) was measured by an agglutination test where a positive titre was $>1 / 20$. Anti-CCP was analysed using the Immunoscan-RA ELISA CCP2 test (Euro-Diagnostica, Malmö, Sweden). A titre above $25 \mathrm{U} / \mathrm{ml}$ was regarded as positive. At inclusion and at follow-up blood samples were centrifuged at $2000 \mathrm{~g}$ and stored at $-80^{\circ} \mathrm{C}$ until analysis.

Frozen serum samples from inclusion and from the follow-up after three months were thawed and analysed in parallel, i.e. all samples from one patient in the same plate, using a sandwich ELISA (AnaMar, Lund). COMP is stable in thawed and refrozen sera. Some of the samples were not thawed before analysis and some were thawed and refrozen. The detection limit of the assay is $<0.1 \mathrm{U} / \mathrm{L}$, and its intra-assay and inter-assay coefficient is $<5 \%$. Samples 
were analysed in duplicate according to the manufacturer's instructions. All analyses were carried out without knowledge of patient characteristics.

Based on changes in serum-COMP over the first 3 months and knowledge of the reference change value (RCV) of COMP, three groups of patients were defined: unchanged serum-COMP levels (change $\leq 20 \%$ ) (group UnCh), increasing levels (increase > 20\%) (group InCr) and decreasing levels (decrease $>20 \%$ ) (group DeCr). Blood samples from the follow-up at 6 months, 1 and 2 years were also analyzed. The RCV value indicates the limit of the normal variation between intra-individual measurements. Variations $20 \%$ or less in serum COMP levels are regarded as a normal biological variation [32-35].

\section{Radiographic examinations}

Plain radiographs of the hands and feet were taken at inclusion, after 1,2 and 5 years. Two readers scored the radiographs independently in chronological order without knowledge of treatment assignment or clinical response. The inter-observer intra-class correlation coefficients between these two readers were above 0.9 for the erosion, joint space narrowing and total Sharp scores. Radiographic damage was scored according to the Sharp method as modified by van der Heijde (SHS), which includes the hands and feet and allows for separate calculations of a total score (range 0-448), an erosion score (range 0-280), and a joint space narrowing (JSN) score (range 0-168) [36]. The smallest detectable change in total SHS was 5.8. Radiographic progression was defined as a change of total SHS of 5.8 or more [37].

\section{Statistical methods}

Statistical analyses were performed using PASW Statistics 18 software. All significance tests were two tailed and conducted at the 0.05 significance level. To test differences between groups Chi2 test was used for proportions and Kruskal-Wallis test with post hoc analysis for continuous variables. A logistic regression analysis was used to determine whether an increase of serum COMP can predict joint damage progress over the five first years with the different groups as categorical variables. A multiple logistic analysis was performed to assess if an increase in serum COMP, between inclusion and 3 months follow-up, of more than $20 \%$ ( $\mathrm{InCr}$ ) compared to stable levels of serum COMP, change of $20 \%$ or less ( $\mathrm{UnCh}$ ), was an independent factor of joint damage progression, i.e. change in SHS of more than 5.8. The multiple logistic analysis were controlled for gender, age, disease duration, anti-CCP, RF, DMARD and prednisolone treatment at inclusion.

\section{Ethical approval}

Ethical approval was obtained from the Ethics Committee, Lund University, Gothenburg University, Linköpings
University and Karolinska Institute (LU 398-01, Gbg 282-01, LI 01-263, KI 02-075). The study followed the guidelines from the Helsinki Declaration. Written consent from the participants was obtained.

\section{Results}

\section{Serum COMP and baseline characteristics}

At baseline, the median (range) serum-COMP level was 12.7 U/L (4.5-32.0).

Clustering patients according to altered COMP levels over 3 months, three groups were identified: Group UnCh, of 142 (41\%) patients with no change in serumCOMP, Figure 1B; group DeCr of 173 (49\%) patients with decreasing serum-COMP-levels, Figure $1 \mathrm{C}$; group $\mathrm{InCr}$, of $34(10 \%)$ patients with increasing serum-COMP levels Figure 1D.

Table 1 shows demographic and baseline disease variables. Except for a higher ESR in group $\mathrm{InCr}$, there were no statistically significant differences between the groups. Notably, the groups did not differ regarding presence of RF or anti-CCP, two putative negative prognostic factors.

At baseline, median serum-COMP differed between the groups being highest in group $\operatorname{DeCr}(13.8 \mathrm{U} / \mathrm{L})$ and lowest in group $\mathrm{InCr}(9.6 \mathrm{U} / \mathrm{L})$ and intermediate in group $\mathrm{UnCh}$ (11.9 U/L), overall $\mathrm{p}<0.001$, Figure $1 \mathrm{~A}$. At three months the median serum-COMP values were lower in the $\mathrm{DeCr}$ group than in both the other two groups, $\mathrm{p}<0.001$. At 6 months the DeCr group had still a lower median serumCOMP than both the InCr group $(\mathrm{p}<0.001)$ and the $\mathrm{UnCh}$ group $(p=0.011)$, but there was no significant difference between the UnCh group and the $\mathrm{InCr}$ group. At 12 months this pattern persisted. At 24 months there were no significant differences for serum-COMP between the groups $(\mathrm{p}=0.142)$.

\section{Treatment during the 5-year period}

There were no significant differences in DMARD treatment between the groups at 3 or 6 months, 1, 2 or 5 years. No patient was treated with biologics before the follow-up visit at 2 years and no difference regarding such treatment between the groups was apparent during the subsequent 3 years. Treatment with prednisolone differed between the groups. A larger number of patients in group $\mathrm{DeCr}$ were treated with prednisolone from inclusion to the 24 month follow-up and fewer patients in group $\mathrm{InCr}$ from the 3 months to the 2 year follow-up. At 5 years there were no differences in this respect between the groups.

\section{Radiographic outcome over 5 years}

Radiographic progression after 5 years (change in total SHS score with 5.8 or more) was significantly more frequent in the InCr group, $71 \%$, than in the other groups, $46 \%$ and $46 \%$ respectively, overall $\mathrm{p}=0.022$. In the $\mathrm{InCr}$ group the median change in erosion score was significantly 


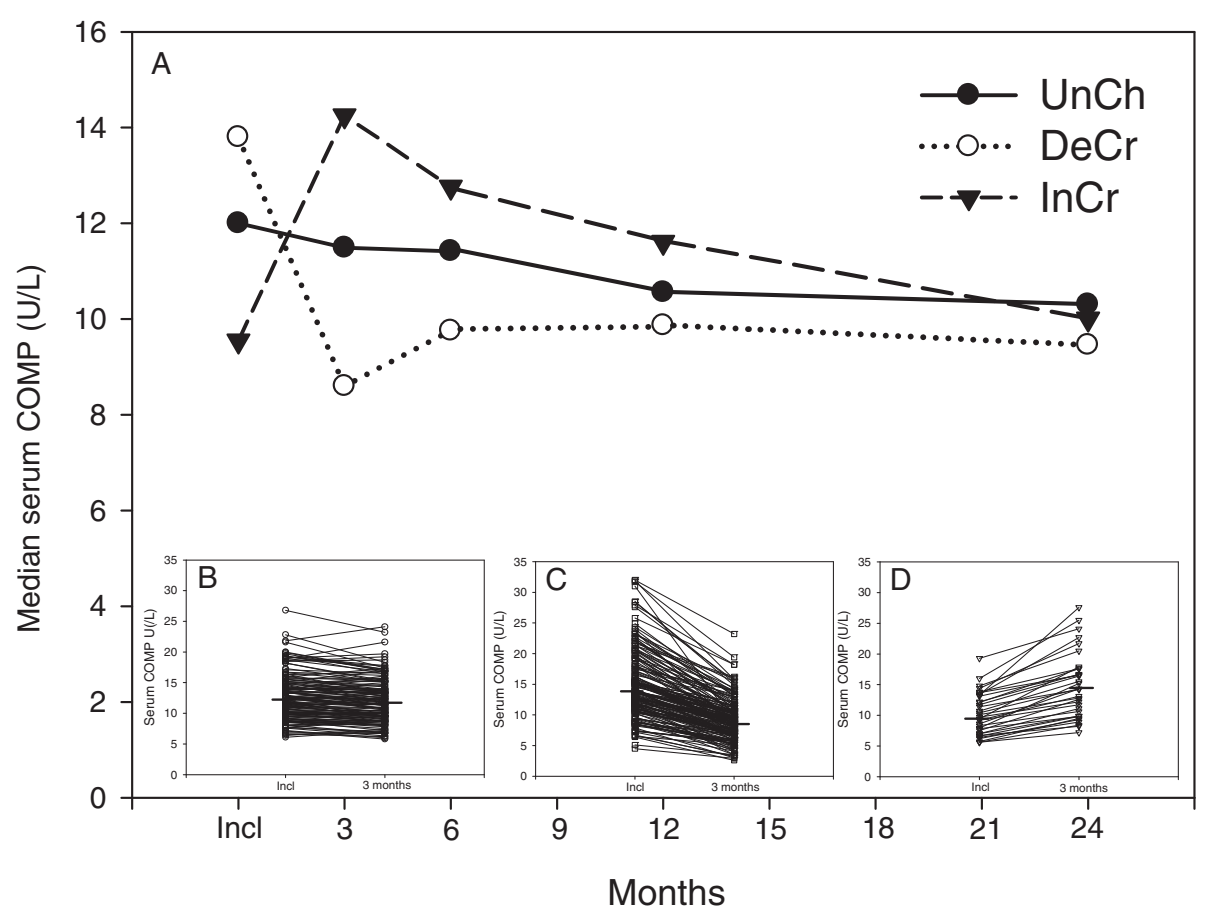

Figure 1 Median value for serum-COMP over the first 2 years in the groups. (A) shows the median value for serum-COMP over the first 2 years in the groups. The inserts show the individual changes between inclusion and the 3 month follow up in the group with unchanged serum-COMP levels (UnCh, $\mathrm{N}=142)(\mathbf{B})$, the group with decreasing levels ( $\mathrm{DeCr}, \mathrm{N}=173)$ (C) and the group with increasing levels (InCr, $\mathrm{N}=34)(\mathbf{D})$.

The median values in the inserts are shown as a horisontal line. For further explanation, see text.

higher compared with that in the other groups at 1,2 and 5 years, Figure 2A. Pair wise comparisons of changes in erosion score indicated significant differences between groups. Thus, group $\mathrm{InCr}$ showed a greater increase in erosion score than the other groups at all time points,
Figure 2A. Similarly, the median change in total SHS was larger in this group but not statistically significant at all time points, Figure $2 \mathrm{C}$. There were no significant differences between the groups regarding change in ISN score Figure 2B.

Table 1 Baseline characteristics at inclusion, median values (range)

\begin{tabular}{|c|c|c|c|c|c|}
\hline & Group UnCh $(\mathrm{N}=142)$ & Group $\operatorname{lnCr}(\mathrm{N}=34)$ & Group DeCr (N=173) & All $(\mathrm{N}=349)$ & P-value* \\
\hline Age & $58(16-83)$ & $56(25-83)$ & $57(18-84)$ & $58(16-84)$ & 0.96 \\
\hline Gender (\% women) & 62 & 56 & 68 & 64 & $0.33^{* *}$ \\
\hline Disease duration (months) & $6.0(1-13)$ & $3.5(1-12)$ & $6.0(1-21)$ & $6,0(1-21)$ & 0.10 \\
\hline DAS28 & $5.4(0.5-7.9)$ & $5.5(0.5-8.0)$ & $5.1(2.3-8.1)$ & $5,3(0,5-8,1)$ & 0.06 \\
\hline $\mathrm{HAQ}$ & $0.9(0-2.6)$ & $1.3(0-2.3)$ & $0.9(0-2.5)$ & $0,9(0-2,6)$ & 0.10 \\
\hline $\operatorname{ESR}(\mathrm{mm} / \mathrm{H})$ & $33(2-110)$ & $42(2-140)$ & $27(2-115)$ & $31(2-140)$ & 0.006 \\
\hline CRP (mg/L) & $22.0(4-186)$ & $29.5(3-159)$ & $19.0(4-228)$ & $21(3-228)$ & 0.40 \\
\hline RF positive (\%) & 61 & 67 & 56 & 59 & $0.46^{* *}$ \\
\hline Anti-CCP (\%) & 58 & 61 & 56 & 57 & $0.86^{* *}$ \\
\hline $\operatorname{COMP}(\mathrm{U} / \mathrm{L})$ & $11.9(6.1-26.8)$ & $9.6(5.6-19.3)$ & $13.8(4.5-32.0)$ & $12.7(4.5-32.0)$ & $<0.001$ \\
\hline Erosion score & $0(0-44)$ & $0(0-20)$ & $0(0-15)$ & $0(0-44)$ & 0.68 \\
\hline JSN score & $0(0-40)$ & $0(0-15)$ & $0(0-33)$ & $0(0-40)$ & 0.41 \\
\hline Total Sharp score & $1(0-84)$ & $2(0-34)$ & $0.25(0-35)$ & $1(0-84)$ & 0.52 \\
\hline
\end{tabular}

Group UnCh, patients with unchanged serum-COMP levels from inclusion to 3 months follow-up (change $\leq 20 \%$ ),

Group InCr, increasing serum- COMP levels from inclusion to 3 months follow-up (increase $>20 \%$ ).

Group DeCr, decreasing serum-COMP levels from inclusion to 3 months follow-up (decrease > 20\%).

*Kruskal-Wallis test, ${ }^{* *}$ Chi2 test. 

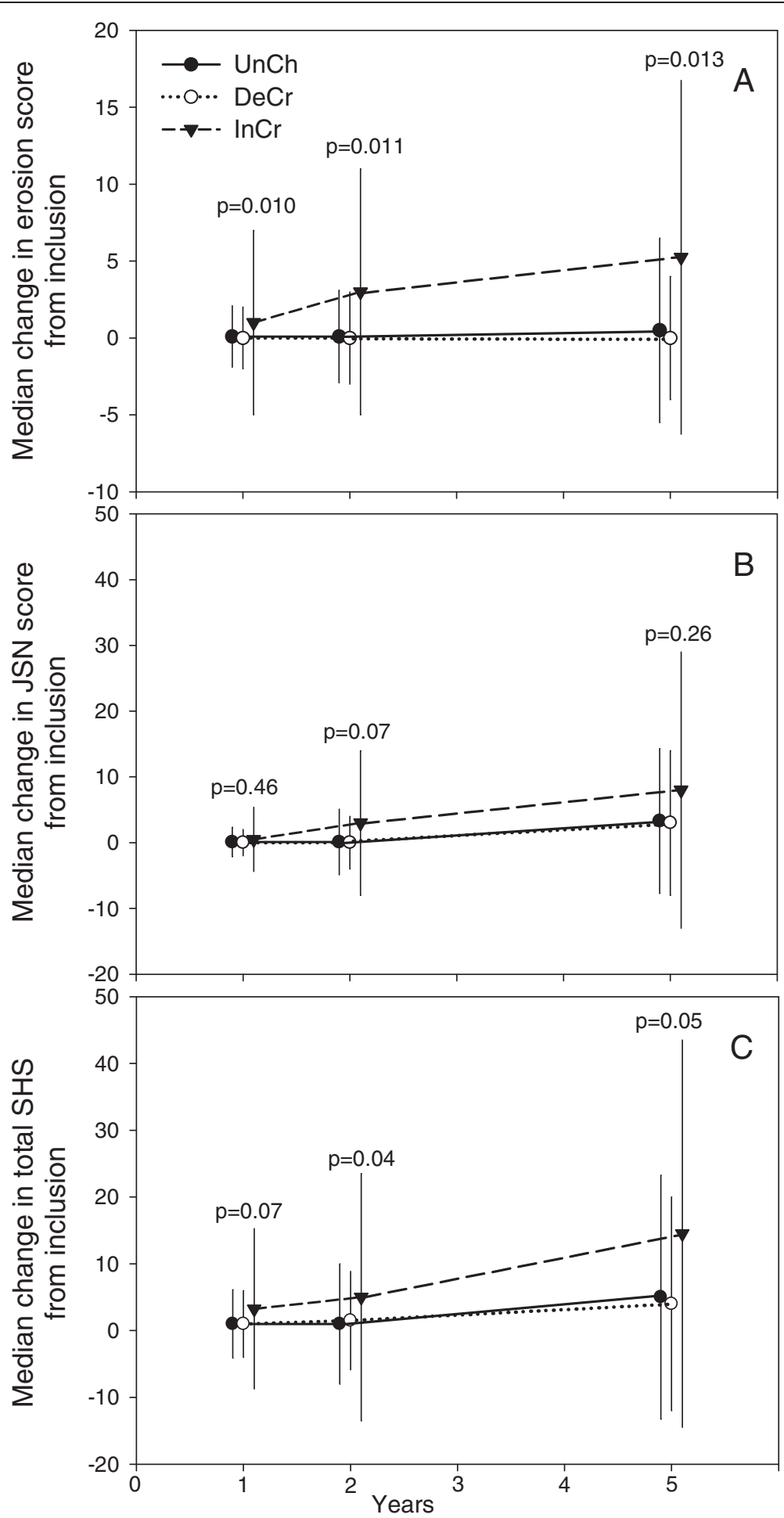

Figure 2 Median change of erosion score (A), joint space narrowing (JSN) (B) and total Sharp van der Heijde score (SHS) (C) between inclusion and the 1, 2 and $\mathbf{5}$ year examinations. Figure 2 shows median change with $75 \% \mathrm{Cl}$ (denoted by vertical lines) of erosion score (A), joint space narrowing (JSN) (B) and total Sharp van der Heijde score (SHS) (C) between inclusion and the 1, 2 and 5 year examinations. Group UnCh, patients with unchanged serum-COMP levels from inclusion to 3 months follow-up (change $\leq 20 \%$ ), Group DeCr, patients with decreasing serum-COMP levels from inclusion to 3 months follow-up (decrease > 20\%) and Group InCr, patients with increasing serum-COMP levels from inclusion to 3 months follow-up (increase > 20\%). P-values denote results of Kruskal-Wallis test between groups at 1, 2 and 5 years. 
In a logistic regression analysis, group $\mathrm{InCr}$ showed an increased risk of radiographic joint damage progression at 5 years compared with group UnCh, OR 2.8 (95\% CI 1.26-6.38), $\mathrm{p}=0.011$. Group DeCr did not differ in this respect from group UnCh. The association remained after controlling for gender, age, disease duration, ESR, anti-CCP, RF, DMARD and prednisolone treatment at inclusion (OR 3.1 (95\% CI 1.2-7.8, p=0.019). There was also an increased risk for patients positive for anti-CCP (OR 4.9 (95\% CI 2.59.7, $\mathrm{p}<0.001)$.

\section{Clinical disease course and remission}

The clinical disease activity measured by DAS28, HAQ, ESR and CRP decreased in all groups during the study period and notably there were no significant differences between the groups for changes in DAS28, HAQ, ESR or CRP between inclusion and 3 months, 1-, 2- and 5 years follow-up, respectively, data not shown. There was also no significant difference in joint count (swollen or tender) between the groups at any time point. At the five year follow-up there were no differences between the groups for these variables, except for ESR which was higher in the $\mathrm{InCr}$ group $(\mathrm{p}=0.02)$. There were no differences at five year follow-up between the groups regarding EULAR or EULAR/ACR remission. The proportion of patients in EULAR remission was 43\% (UnCh group), $34 \%$ ( $\mathrm{InCr}$ group) and 45\% ( $\mathrm{DeCr}$ group), $\mathrm{p}=0.51$, respectively and the proportion in ACR/EULAR remission was $10 \%, 6 \%$ and $10 \%$, respectively, $\mathrm{p}=0.81$.

\section{Discussion}

In this study we have introduced a novel approach to detect in serum samples a destructive process in one or several affected joints in patients with early RA. The background knowledge is that turnover in all the cartilages in the body is rather constant and typical for the individual, while changing when there is an activated or inhibited process in one or few cartilages. Thus, changes in serum concentrations of a molecule derived from the cartilage could be an indicator of an altered activity of the process. We have consequently assessed the relevance of altered serum concentrations of COMP, as a tool for demonstrating activity in the joint and to determine whether this could indeed be used as an indicator to signal risk for progressive joint destruction in RA. We measured the alterations in serum COMP from inclusion at early stage disease and until 3 months in a prospectively monitored early RA cohort.

By assessing this change in COMP level we could identify 3 different patient groups with unchanged, decreasing or increasing serum concentrations of COMP and compared the radiological progression of joint damage in hands and feet over a 5 year period between these 3 groups. The important main finding in support of the concept was that the small group of patients showing increased serum concentrations during the initial 3-month period, i.e. more than $20 \%$ compared to baseline, progressed significantly more than the other groups and had a more marked increase in erosion score and total SHS score at the 1, 2 and 5 year follow-up, although not significant for total SHS.

The fact that the group with increasing levels was small is not unexpected, considering that marked joint damage progression is seen only in a small proportion of patients with early RA over a 5-year period [38].

Notably, the groups did not differ regarding radiographic appearance at inclusion although the COMP levels did. Remarkably, serum COMP was lowest in the group with the largest progression but there was no association between baseline S-COMP and radiographic progression assessed according to Sharp van der Heijde at 1, 2 or 5 years (data not shown). There was also no significant associations between follow-up S-COMP at any time point and any clinical or radiographic outcome variable. These findings suggest that a single measurement does not provide a prognostic value.

Interestingly, those patients with an increasing tissue turnover activity in the early phase of the process reflected by COMP release are those who will progress the most. Other molecular indicators should be tested in a similar fashion to find out whether this is generally applicable.

It is somewhat surprising that the association between erosion score and COMP changes was more pronounced than that between COMP changes and JSN. However, the cartilage and bone processes seem closely interlinked [39]. One reason for this finding could be related to the sensitivity of the scoring system. Thus in clinical trials of potentially damage protective drugs, differences between treatment groups are often most marked for the erosion score [40].

There were essentially no differences between the groups regarding demographic characteristics and for baseline disease variables. The only difference was a somewhat higher ESR in the InCr group, which may reflect a more pronounced inflammatory process in these patients. This is not unexpected in view of the link between inflammation and joint damage progression $[4,41,42]$. However, there were no differences between the groups regarding changes in ESR or CRP during the study and the groups were clinically indistinguishable at five years. Furthermore, the groups did not differ regarding presence of RF or anti-CCP, which clearly suggests that the approach to evaluate prognosis regarding progression of joint damage introduced in this report adds to the armamentarium of prognostic indicators in RA.

It is important to note that the patients were treated differently with respect to glucocorticoids, i.e. more patients in the DeCr group were treated with prednisolone. Glucocorticoids are known to retard joint damage at 
least during the first 2 years of disease and reduce serum concentrations of COMP [43-46]. Thus the decreasing COMP levels and less progression of joint damage may be related to the prednisolone treatment in this subgroup.

A limitation to the study is that we had only access to serum samples at 0 and 3 months during the first 3 months. Analyses of samples obtained more frequently may have further strengthened the findings and importantly, would be advantageous in a clinical setting for making early treatment decisions.

An important strength of this study is the prospective setting with regular monitoring of the patients including radiographic examinations and scoring in a systematic fashion.

\section{Conclusion}

In conclusion, we have shown that analyses of changes of serum COMP between inclusion and a 3 month follow up in patients with early RA could distinguish patients with different rates of joint damage progression over a 5 year period. Patients with increasing COMP concentrations showed the most marked progression. This approach should be further investigated, particularly by assessing the utility of examining samples obtained over a shorter time interval which potentially could improve the sensitivity and clinical feasibility.

\section{Competing interests}

$\mathrm{DH}, \mathrm{TS}$ are co-founders and minor shareholders of AnaMar, IFP is member of the board of AnaMar. The other authors declare no competing interests.

\begin{abstract}
Authors contributions
MA participated in planning the study design, gathered the data from the database, analysed the blood samples, performed the statistical analyses, and drafted the manuscript. BS participated in planning the study design, statistical analyses, data interpretation and helped draft the manuscript. IP participated in planning the study design, data interpretation and critically revised the manuscript $\mathrm{IH}$ participated in planning the study design, data interpretation and critically revised the manuscript. KA participated in planning the study design, read the radiographs and critically revised the manuscript. KF participated in planning the study design, read the radiographs and critically revised the manuscript. DH participated in planning the study design, data interpretation and critically revised the manuscript. TS participated in planning the study design, data interpretation and helped draft the manuscript. All authors read and approved the final manuscript.
\end{abstract}

\section{Acknowledgements}

Other members of the BARFOT Study Group the authors would like to thank include Sofia Ajeganova, Valentina Bala, Stefan Bergman, Kristina Forslind, Catharina Keller, Ido Leden, Bengt Lindell, Christoffer Schaufelberger, Maria Söderlin, Annika Teleman, Jan Theander and Anneli Östenson This work was supported by grants from the Swedish Medical Research Council, the Medical Faculty of Lund University, the Swedish Rheumatism Association, King Gustaf V 80-year Fund, the Österlund Foundation, the Kock Foundation, The County Council of Halland research fund and The Regional board of Southern Sweden research fund.

\section{Author details}

${ }^{1} R$ and D center, Spenshult Hospital, Oskarström, Sweden. ${ }^{2}$ Department of Clinical Sciences, Lund, Section of Rheumatology, Lund University, Lund, Sweden. ${ }^{3}$ Department of Rheumatology, Karolinska Institutet, Karolinska University Hospital, Huddinge, Sweden. ${ }^{4}$ Section of Rheumatology,
Department of Internal medicine Helsingborgs Lasarett, Helsingborgs Lasarett, Helsingborg, Sweden.

Received: 5 February 2013 Accepted: 29 July 2013

Published: 2 August 2013

\section{References}

1. Katchamart W, Johnson S, Lin HJ, Phumethum V, Salliot C, Bombardier C: Predictors for remission in rheumatoid arthritis patients: A systematic review. Arthritis Care Res (Hoboken) 2010, 62:1128-1143.

2. Scott DL, Smith C, Kingsley G: Joint damage and disability in rheumatoid arthritis: an updated systematic review. Clin Exp Rheumatol 2003, 21:S20-S27.

3. Welsing PM, van Gestel AM, Swinkels HL, Kiemeney LA, van Riel PL: The relationship between disease activity, joint destruction, and functional capacity over the course of rheumatoid arthritis. Arthritis Rheum 2001, 44:2009-2017.

4. Wick MC, Lindblad S, Klareskog L, Van Vollenhoven RF: Relationship between inflammation and joint destruction in early rheumatoid arthritis: a mathematical description. Ann Rheum Dis 2004, 63:848-852.

5. Pincus T, Sokka T: Laboratory tests to assess patients with rheumatoid arthritis: advantages and limitations. Rheum Dis Clin North Am 2009, 35:731-734. vi-vii.

6. Pincus T, Yazici Y, Sokka T: Complexities in assessment of rheumatoid arthritis: absence of a single gold standard measure. Rheum Dis Clin North Am 2009, 35:687-697.

7. Sokka T, Toloza S, Cutolo M, Kautiainen H, Makinen H, Gogus F, Skakic V, Badsha H, Peets T, Baranauskaite A, et al: Women, men, and rheumatoid arthritis: analyses of disease activity, disease characteristics, and treatments in the QUEST-RA study. Arthritis Res Ther 2009, 11:R7.

8. Schoels M, Bombardier C, Aletaha D: Diagnostic and prognostic value of antibodies and soluble biomarkers in undifferentiated peripheral inflammatory arthritis: a systematic review. J Rheumatol Suppl 2011, 87:20-25.

9. Hedbom E, Antonsson P, Hjerpe A, Aeschlimann D, Paulsson M, Rosa-Pimentel E, Sommarin Y, Wendel M, Oldberg A, Heinegard D: Cartilage matrix proteins. An acidic oligomeric protein (COMP) detected only in cartilage. J Biol Chem 1992, 267:6132-6136.

10. Saxne T, Heinegard D: Cartilage oligomeric matrix protein: a novel marker of cartilage turnover detectable in synovial fluid and blood. $\mathrm{Br} J$ Rheumatol 1992, 31:583-591.

11. Larsson E, Erlandsson Harris H, Lorentzen JC, Larsson A, Mansson B, Klareskog L, Saxne T: Serum concentrations of cartilage oligomeric matrix protein, fibrinogen and hyaluronan distinguish inflammation and cartilage destruction in experimental arthritis in rats. Rheumatol (Oxford) 2002, 41:996-1000.

12. Crnkic M, Mansson B, Larsson L, Geborek P, Heinegard D, Saxne T: Serum cartilage oligomeric matrix protein (COMP) decreases in rheumatoid arthritis patients treated with infliximab or etanercept. Arthritis Res Ther 2003, 5:R181-R185

13. de Jong Z, Munneke M, Vilim V, Zwinderman AH, Kroon HM, Ronday HK, Lems WF, Dijkmans BA, Breedveld FC, Vliet Vlieland TP, et al: Value of serum cartilage oligomeric matrix protein as a prognostic marker of large-joint damage in rheumatoid arthritis-data from the RAPIT study. Rheumatol (Oxford) 2008, 47:868-871.

14. Lindqvist E, Eberhardt K, Bendtzen K, Heinegard D, Saxne T: Prognostic laboratory markers of joint damage in rheumatoid arthritis. Ann Rheum Dis 2005, 64:196-201.

15. Mansson B, Carey D, Alini M, lonescu M, Rosenberg LC, Poole AR, Heinegard D, Saxne T: Cartilage and bone metabolism in rheumatoid arthritis. Differences between rapid and slow progression of disease identified by serum markers of cartilage metabolism. J Clin Invest 1995, 95:1071-1077.

16. Morozzi G, Fabbroni M, Bellisai F, Pucci G, Galeazzi M: Cartilage oligomeric matrix protein level in rheumatic diseases: potential use as a marker for measuring articular cartilage damage and/or the therapeutic efficacy of treatments. Ann N Y Acad Sci 2007, 1108:398-407.

17. Sharif M, Saxne T, Shepstone L, Kirwan JR, Elson CJ, Heinegard D, Dieppe PA: Relationship between serum cartilage oligomeric matrix protein levels and disease progression in osteoarthritis of the knee joint. Br J Rheumatol 1995, 34:306-310

18. Bruyere O, Collette JH, Ethgen O, Rovati LC, Giacovelli G, Henrotin YE, Seidel L, Reginster JY: Biochemical markers of bone and cartilage remodeling in 
prediction of longterm progression of knee osteoarthritis. J Rheumatol 2003, 30:1043-1050.

19. Fex E, Eberhardt $K$, Saxne T: Tissue-derived macromolecules and markers of inflammation in serum in early rheumatoid arthritis: relationship to development of joint destruction in hands and feet. Br J Rheumatol 1997, 36:1161-1165.

20. Syversen SW, Goll GL, van der Heijde D, Landewe R, Gaarder PI, Odegard S, Haavardsholm EA, Kvien TK: Cartilage and bone biomarkers in rheumatoid arthritis: prediction of 10-year radiographic progression. J Rheumatol 2009, 36:266-272.

21. Conrozier T, Saxne T, Fan CS, Mathieu P, Tron AM, Heinegard D, Vignon E: Serum concentrations of cartilage oligomeric matrix protein and bone sialoprotein in hip osteoarthritis: a one year prospective study. Ann Rheum Dis 1998, 57:527-532.

22. Georges C, Vigneron H, Ayral X, Listrat V, Ravaud P, Dougados M, Sharif M, Dieppe $P$, Saxne T: Serum biologic markers as predictors of disease progression in osteoarthritis of the knee. Arthritis Rheum 1997, 40:590-591.

23. Petersson IF, Boegard T, Svensson B, Heinegard D, Saxne T: Changes in cartilage and bone metabolism identified by serum markers in early osteoarthritis of the knee joint. Br J Rheumatol 1998, 37:46-50.

24. Williams FM, Andrew T, Saxne T, Heinegard D, Spector TD, MacGregor AJ: The heritable determinants of cartilage oligomeric matrix protein. Arthritis Rheum 2006, 54:2147-2151.

25. Arnett FC, Edworthy SM, Bloch DA, McShane DJ, Fries JF, Cooper NS, Healey LA, Kaplan SR, Liang MH, Luthra HS, et al: The American Rheumatism Association 1987 revised criteria for the classification of rheumatoid arthritis. Arthritis Rheum 1988, 31:315-324.

26. Svensson B, Schaufelberger C, Teleman A, Theander J: Remission and response to early treatment of RA assessed by the Disease Activity Score. BARFOT study group. Better Anti-rheumatic Farmacotherapy. Rheumatol (Oxford) 2000, 39:1031-1036.

27. Prevoo ML, Hof MA V 't, Kuper HH, Van Leeuwen MA, Van de Putte LB, Van Riel PL: Modified disease activity scores that include twenty-eight-joint counts. Development and validation in a prospective longitudinal study of patients with rheumatoid arthritis. Arthritis Rheum 1995, 38:44-48.

28. Fransen J, van Riel PL: DAS remission cut points. Clin Exp Rheumatol 2006, 24:29-32.

29. Landewe R, van der Heijde $D$, van der Linden S, Boers M: Twenty-eightjoint counts invalidate the DAS28 remission definition owing to the omission of the lower extremity joints: a comparison with the original DAS remission. Ann Rheum Dis 2006, 65:637-641.

30. Felson DT, Smolen JS, Wells G, Zhang B, van Tuyl LH, Funovits J, Aletaha D, Allaart CF, Bathon J, Bombardieri S, et al: American college of rheumatology/european league against rheumatism provisional definition of remission in rheumatoid arthritis for clinical trials. Ann Rheum Dis 2011, 70:404-413.

31. Ekdahl C, Eberhardt K, Andersson SI, Svensson B: Assessing disability in patients with rheumatoid arthritis. Use of a Swedish version of the Stanford Health Assessment Questionnaire. Scand J Rheumatol 1988, 17:263-271.

32. Brescia V, Tampoia M: Biological variation of Cartilage Oligomeric Matrix Protein (COMP): A proposal to interpret laboratory serial testing. Clin Chim Acta 2007.

33. Ricos C, Alvarez V, Cava F, Garcia-Lario JV, Hernandez A, Jimenez CV, Minchinela J, Perich C, Simon M: Integration of data derived from biological variation into the quality management system. Clin Chim Acto 2004, 346:13-18.

34. Ricos C, Cava F, Garcia-Lario JV, Hernandez A, Iglesias N, Jimenez CV, Minchinela J, Perich C, Simon M, Domenech MV, Alvarez V: The reference change value: a proposal to interpret laboratory reports in serial testing based on biological variation. Scand J Clin Lab Invest 2004, 64:175-184.

35. Ricos C, Iglesias N, Garcia-Lario JV, Simon M, Cava F, Hernandez A, Perich C, Minchinela J, Alvarez V, Domenech MV, et al: Within-subject biological variation in disease: collated data and clinical consequences. Ann Clin Biochem 2007, 44:343-352.

36. van der Heijde D: How to read radiographs according to the Sharp/van der Heijde method. J Rheumatol 2000, 27:261-263.

37. Svensson B, Boonen A, Albertsson K, van der Heijde D, Keller C, Hafstrom I: Low-dose prednisolone in addition to the initial disease-modifying antirheumatic drug in patients with early active rheumatoid arthritis reduces joint destruction and increases the remission rate: a two-year randomized trial. Arthritis Rheum 2005, 52:3360-3370.
38. Hetland ML, Stengaard-Pedersen $\mathrm{K}$, Junker P, Ostergaard M, Ejbjerg BJ, Jacobsen S, Lottenburger T, Hansen I, Tarp U, Andersen LS, et al: Radiographic progression and remission rates in early rheumatoid arthritis - MRI bone oedema and anti-CCP predicted radiographic progression in the 5-year extension of the double-blind randomised CIMESTRA trial. Ann Rheum Dis 2010, 69:1789-1795.

39. Heinegard D: Proteoglycans and more-from molecules to biology. Int J Exp Pathol 2009, 90:575-586.

40. Smolen JS, van der Heijde DM, Aletaha D, Xu S, Han J, Baker D, St Clair EW: Progression of radiographic joint damage in rheumatoid arthritis: independence of erosions and joint space narrowing. Ann Rheum Dis 2009, 68:1535-1540.

41. Graudal N, Tarp U, Jurik AG, Galloe AM, Garred P, Milman N, Graudal HK: Inflammatory patterns in rheumatoid arthritis estimated by the number of swollen and tender joints, the erythrocyte sedimentation rate, and hemoglobin: longterm course and association to radiographic progression. J Rheumatol 2000, 27:47-57.

42. Plant MJ, Williams AL, O'Sullivan MM, Lewis PA, Coles EC, Jessop JD: Relationship between time-integrated C-reactive protein levels and radiologic progression in patients with rheumatoid arthritis. Arthritis Rheum 2000, 43:1473-1477.

43. Hafstrom I, Albertsson K, Boonen A, van der Heijde D, Landewe R, Svensson B: Remission achieved after 2 years treatment with low-dose prednisolone in addition to disease-modifying anti-rheumatic drugs in early rheumatoid arthritis is associated with reduced joint destruction still present after 4 years: an open 2-year continuation study. Ann Rheum Dis 2009, 68:508-513.

44. Larsson E, Erlandsson Harris H, Larsson A, Mansson B, Saxne T, Klareskog L: Corticosteroid treatment of experimental arthritis retards cartilage destruction as determined by histology and serum COMP. Rheumatol (Oxford) 2004, 43:428-434.

45. Skoumal M, Haberhauer G, Feyertag J, Kittl EM, Bauer K, Dunky A: Serum levels of cartilage oligomeric matrix protein (COMP): a rapid decrease in patients with active rheumatoid arthritis undergoing intravenous steroid treatment. Rheumatol Int 2006, 26:1001-1004.

46. Weitoft T, Larsson A, Saxne T, Ronnblom L: Changes of cartilage and bone markers after intra-articular glucocorticoid treatment with and without postinjection rest in patients with rheumatoid arthritis. Ann Rheum Dis 2005, 64:1750-1753.

doi:10.1186/1471-2474-14-229

Cite this article as: Andersson et al.: Early increase in serum-COMP is associated with joint damage progression over the first five years in patients with rheumatoid arthritis. BMC Musculoskeletal Disorders 2013 14:229.

\section{Submit your next manuscript to BioMed Central and take full advantage of:}

- Convenient online submission

- Thorough peer review

- No space constraints or color figure charges

- Immediate publication on acceptance

- Inclusion in PubMed, CAS, Scopus and Google Scholar

- Research which is freely available for redistribution 